\title{
PENGARUH KEPEMIMPINAN ISLAMI DAN KINERJA PEMERINTAH DAERAH TERHADAP PEMBANGUNAN EKONOMI DI KOTA TANGERANG SELATAN DENGAN PENDEKATAN HAHSLM
}

\author{
Engkur ${ }^{1}$, Roikhan Mochamad Aziz ${ }^{2}$ dan Doni Wiratmoko ${ }^{3}$ \\ ${ }^{1}$ STEI Indonesia Jakarta \\ ${ }^{2,3}$ UIN Jakarta \\ ${ }^{1}$ engkurdsh@gmail.com \\ 2ush472319@gmail.com \\ 33wiratmokodonimoko@gmail.com
}

\begin{abstract}
Abstrak - Kota Tangerang Selatan saat ini mengalami kemajuan dan perkembangan setelah adanya pemekaran daerah. Tentunya itu semua tidak luput dari kepemimpinan kepala daerah tersebut. Penelitian ini bertujuan untuk menganalisis pengaruh kepemimpinan Islami kepala daerah dan kinerja pemerintahan daerah terhadap pembangunan ekonomi di kota Tangerang Selatan. Data yang digunakan pada penelitian ini adalah data primer yang diperoleh dari kuesioner yang disebar pada masyarakat kota Tangerang Selatan. Metode analisis data yang digunakan adalah Metode Partial Least Square (PLS) dengan Software SmartPLS 2.0 dan Microsoft Excel 2010. Hasil dari penelitian ini menunjukkan bahwa variabel kepemimpinan Islami berpengaruh signifikan terhadap pembangunan ekonomi di Kota Tangerang Selatan, dengan nilai signifikansi sebesar 0.000 lebih kecil dari signifikansi yang digunakan yaitu 0.05. Variabel kepemimpinan Islami juga berpengaruh signifikan terhadap akuntabilitas kinerja pemerintah daerah di Kota Tangerang Selatan. Sedangkan variabel akuntabilitas kinerja pemerintah daerah tidak berpengaruh signifikan terhadap pembangunan ekonomi di Kota Tangerang Selatan dengan nilai t-statistik 1.063 lebih kecil dari t-tabel yaitu sebesar 1.96 dan nilai signifikansi sebesar 0.288 lebih besar dari dari signifikansi yang digunakan yaitu 0.05 .
\end{abstract}

Keywords: Kepemimpinan, Kepemimpinan Islami, kinerja,Akuntabilitas, pembangunan ekonomi, PLS 


\section{PENDAHULUAN}

\subsection{Latar Belakang}

Kepemimpinan merupakan faktor penting dalam suatu organisasi. Dalam perspektif Islam bahwa setiap perbuatan yang dilakukan akan dimintai pertanggung jawabannya, termasuk kepemimpinan yang merupakan amanah dari Allah SWT. Dapat dilihat dari banyaknya dalil yang menjelaskan tentang pertanggung jawaban kepemimpinan. Allah SWT berfirman: "Tiap-tiap diri bertanggung jawab atas apa yang telah diperbuatnya". (QS. Al-Mudatstsir: 38). Dalam surat lain Allah SWT berfirman: "Sesungguhnya pendengaran, penglihatan dan hati, semuanya itu akan dimintai pertanggung jawabannya." (QS. Al Isra': 36). Juga secara jelas Nabi Muhammad bersabda mengenai pertanggung jawaban dari kepemimpinan: "Ketahuilah bahwa setiap kamu adalah pemimpin dan setiap pemimpin bertanggung jawab atas kepemimpinannya. Setiap kepala negara adalah pemimpin dan ia bertanggung jawab atas kepemimpinannya (rakyat). Seorang perempuan/ibu adalah pemimpin dalam rumah tangga suaminya dan anak-anaknya; ia bertanggung atas kepemimpinannya. Seorang pelayan/hamba sahaya adalah pemimpin atas harta tuannya dan ia bertanggung jawab atas kepemimpinannya. Ketahuilah bahwa setiap kamu adalah pemimpin dan masing-masing mempertanggung jawabkan atas kepemimpinannya". (HR. Bukhori, Muslim, Ahmad, Abu Dawud, Tirmidzi dari Ibnu Umar).

Berdasarkan dalil-dalil di atas, dapat dipahami bahwa kepemimpinan merupakan amanah. Yaitu seorang pemimpin harus menjalankan kepemimpinannya dengan cara melayani dan mengurusi urusan rakyat yang berada di bawah kepemimpinannya (Fithrah, 2017). Beberapa mekanisme pemenuhan kebutuhan pokok masyarakat melalui cara tidak langsung dilakukan terhadap kebutuhan bersifat individual /barang, sementara kebutuhan jasa atau kebutuhan bersama berupa pendidikan, kesehatan dan keamanan dijamin secara langsung pemenuhannya oleh Negara dengan cara menyediakan berbagai fasilitasfasilitas kebutuhan tersebut, seperti sarana pendidikan (sekolah), sarana kesehatan (rumah sakit) dan jaminan keamanan. Semua itu dilakukan dan diberikan oleh Negara kepada masyarakat sebagai upaya mewujudkan kehidupan masyarakat yang sejahtera, adil, makmur serta merata.

Dalam perspektif Islam kepemimpinan dikenal dengan istilah "Imamah, Imaroh, dan Khilafah". Berbagai istilah tersebut memiliki makna sama yakni, kepemimpinan (leadership). Adapun orang yang menjalankannya kepemimpinan juga menggunakan tiga istilah, yaitu Khalifah, Imam, dan Amirul Mukminin. Ketiga istilah tersebut dinyatakan di dalam hadist-hadist shaheh dan ijma' sahabat. Menurut Zallum yang dikutip Fithrah (2017) berpendapat istilah Khalifah, Imam dan Amirul Mukminin adalah orang yang mewakili umat (rakyat) dalam menjalankan pemerintahan, kekuasaan, dan penerapan hukum-hukum syara'. Merurut Djunaedi (2005) persoalan kepemimpinan (leadership) pada dekade terakhir menjadi persoalan yang signifikan dalam hubungannya dengan kesuksesan sebuah organisasi pada level apapun. Suksesnya kepemimpinan dalam Islam yang paling sederhana yaitu diukur dari sejauh mana implementasi amanah yang melekat pada sebuah kekuasaan dapat dijalankan secara profesional.

Tercapainya tujuan pembangunan melalui otonomi daerah yang bersifat desentralistik sangat ditentukan oleh faktor pemimpin dan kepemimpinan yang 
ada. Karena pembangunan melalui otonomi daerah, faktor pemimpin menjadi sorotan dari pelaksanaan pembangunan yang dilaksanakan. Dengan demikian, tercapai tidaknya tujuan pembangunan yang dicanangkan sangat ditentukan oleh upaya pemimpin pada suatu daerah.

Pelaksanaan otonomi daerah sejak tahun 1999 itu telah banyak memberikan kemajuan terhadap pembangunan di daerah. Sejak dijalankannya otonomi daerah salah satu daerah yang merasakan manfaatnya adalah kota Tangerang Selatan. Dapat dilihat saat ini di seluruh wilayah Kota Tangerang Selatan mengalami kemajuan dan perkembangan pembangunan khususnya di bidang infrastruktur jalan dan bangunan, kebersihan, pendidikan dan kesehatan. Arus investasi dan aktifitas perekonomian yang digerakkan sektor swasta terus meningkat hingga dapat meningkatkan laju pertumbuhan ekonomi (8,9 \%), Produk Domestik Regional Bruto serta pendapatan per kapita masyarakat (Bappeda Tangerang Selatan, 2016).

Selain itu, pemahaman sistem ekonomi yang Islami senantiasa mengacu pada konsep Islam yang menyeluruh atau kafah. Pendekatan Islam kafah ini mengandung makna adanya ekspos mengenai iman, Islam, dan ihsan. Tiga hal diskursus ini diperkuat oleh rukun Islam yaitu: 1) Syahadat , 2) Shalat, 3) Zakat dan keempat pusa serta kelima haji.

Resultan dari 3 pilar dalam Islam ini terejawantahkan pada teori dasar ekonomi Islam yang terdiri dari: 1) Teori Tauhid, 2) Teori Ibadah, 3) Teori Maslahah. Implementasi dari pilar utama ekonomi ini sejalan dengan perkembangan perbankan yang ada di Indonesia (Aziz, 2017).

Sejauh mana faktor kepemimpinan Islami dan kinerja pemerintah mempengaruhi pembangunan di kota Tangerang selatan, merupakan tujuan dari penelitian ini. Dengan latar belakang pemimpin dan mayoritas masyarakat beragama Islam, maka kepemimpinan dan kinerja selayaknya mencirikan kepemimpinan yang Islami yaitu sesuai dengan Al-quran dan Sunnah. Oleh karena itu penulis melakukan penelitian tentang "Pengaruh Kepemimpinan Islami Kepala Daerah dan Kinerja Pemerintah Daerah terhadap Pembangunan Ekonomi di Kota Tangerang Selatan”.

\subsection{Rumusan Masalah}

Adapun rumusan masalah dalam penelitian ini adalah sebagai berikut:

1. Bagaimana pengaruh kepemimpinan Islami kepala daerah terhadap pembangunan ekonomi di Kota Tangerang Selatan?

2. Bagaimana pengaruh kepemimpinan Islami kepala daerah terhadap kinerja pemerintah daerah?

3. Bagaimana pengaruh kinerja pemerintah daerah terhadap pembangunan ekonomi di Kota Tangerang Selatan?

\subsection{Tujuan Penelitian}

Adapun tujuan dari penelitian ini adalah sebagai berikut:

1. Untuk menganalisis pengaruh kepemimpinan Islami kepala daerah terhadap pembangunan ekonomi di Kota Tangerang Selatan

2. Untuk menganalisis pengaruh kepemimpinan Islami kepala daerah terhadap kinerja pemerintah daerah 
3. Untuk menganalisis pengaruh kinerja pemerintah daerah terhadap pembangunan ekonomi di Kota Tangerang Selatan

\subsection{Manfaat Penelitian}

Adapun manfaat yang diharapkan dalam penelitian ini adalah:

1. Penelitian ini diharapkan dapat menambah sumber pengetahuan, rujukan serta acuan dalam bidang ilmu ekonomi syariah. Khususnya yang berkaitan dengan pembangunan ekonomi di kota Tangerang Selatan dalam hal kepemimpinan Islami pemerintah daerah dan kinerja pemerintahan.

2. Memberikan masukan kepada pemerintah sehubungan dengan kebijakan pemerintah dalam hal kepemimpinan Islami, kinerja pemerintahan dan pembangunan ekonomi di kota Tangerang Selatan.

3. Menjadi referensi penelitian berikutnya, jika melakukan penelitian dengan topik yang sama. Dan kontribusi riset pembangunan ekonomi.

\section{TINJAUAN PUSTAKA}

\subsection{Landasan Teori}

2.1.1. Pengertian Kepemimpinan

Secara etimologi, istilah kepemimpinan dalam Kamus Besar Bahasa Indonesia (KBBI) berasal dari kaat dasar "pimpin". Dengan mendapat awalan me menjadi "memimpin" yang berarti menuntun, menunjukkan jalan dan membimbing. Perkataan memimpin bermakna sebagai kegiatan, sedangkan yang melaksanakannya disebut pemimpin. Jadi kata pemimpin itu sendiri mempunyai makna: "orang yang memimpin". Bertolak dari kata pemimpin berkembang pula kata kepemimpinan yang menunjukkan semua perihal dalam memimpin, termasuk juga kegiatannya. Jadi kepemimpinan adalah cara untuk memimpin.

Dari segi bahasa, kepemimpinan berasal dari bahasa Inggris dan dikenal dengan kata leadership yang berasal dari kata "leader". Kata ini muncul sekitar tahun 1300-an. Sedangkan kata leadership muncul kemudian sekitar tahun 1700an. Hingga tahun 1940-an, kajian tentang kepemimpinan didasarkan pada teori sifat. Teori ini terbatas hanya mencari sifat-sifat kepribadian, sosial, fisik atau intelektual yang membedakan antara pemimpin dan bukan pemimpin. Artinya, kepemimpinan itu dibawa sejak lahir atau bakat bawaan (Rivai, 2013).

Kepemimpinan adalah proses hubungan antar pribadi yang di dalamnya ada seseorang yang mempengaruhi sikap dan perilaku orang lain. Soehardi Sigit (2001) dalam bukunya Teori Kepemimpinan dalamManajemen, mengatakan bahwa kepemimpinan adalah hubungan antara orang dan pemimpin di mana di dalamnya saling mempengaruhi agar mau bekerjasama berbagi tugas untuk mencapai keinginan sang pemimpin.

Selanjutnya, menurut Mulyono dan Kurniawan (2013), kepemimpinan adalah sebuah ikatan emosi antara pengikut dengan pemimpin dan dengan tujuannya. Menurutnya pada tingkat emosional, pemimpin menciptakan pengikut, sebab mereka menghasilkan dan memunculkan: (1) kepercayaan kepada orang yang tertakuti; (2) kepastian kepada orang yang ragu-ragu; (3) tindakan di mana terdapat keraguan; (4) kekuatan di mana terdapat kelemahan; (5) keahlian di mana 
terdapat kebodohan; (6) keberanian di mana terdapat kepengecutan; (7) optimisme di mana terdapat sinisme; dan (8) keyakinan bahwa masa depan akan lebih baik.

\subsubsection{Pengertian Kepemimpinan Islami}

Sementara itu kepemimpinan dalam Islam tidak jauh berbeda dengan konsep kepemimpiann pada umumnya. Adapun yang membedakan antara kepemimpinan Islam dengan kepemimpinan pada umumnya dilihat dari prinsip dasar dan tujuan kepemimpinan itu sendiri, yang dapat dilihat dari pelaksananya. Di dalam Islam, kepemimpinan merupakan sunnatullah (Fitrah, 2017). Hal demikian berdasarkan hadist Nabi Muhammad SAW, Artinya:"Ketahuilah bahwa setiap kamu adalah pemimpin dan setiap pemimpin bertanggung jawab atas kepemimpinannya. Setiap kepala negara adalah pemimpin dan ia bertanggung jawab atas kepemimpinannya (rakyat). Seorang perempuan/ibu adalah pemimpin dalam rumah tangga suaminya dan anak-anaknya; ia bertanggung atas kepemimpinannya. Seorang pelayan/hamba sahaya adalah pemimpin atas harta tuannya dan ia bertanggung jawab atas kepemimpinannya. Ketahuilah bahwa setiap kamu adalah pemimpin dan masing-masing mempertanggung jawabkan atas kepemimpinannya". (HR. Bukhori, Muslim, Ahmad, Abu Dawud, Tirmidzi dari Ibnu Umar).

Menurut Hakim (2011), filsafat Islam dari kehidupan kepemimpinan dianggap sebagai kepercayaan dan tanggung jawab yang tidak hanya bertanggung jawab untuk anggota di bawah kepemimpinannya, tetapi juga bertanggung jawab di hadapan Allah SWT sebagaimana dinyatakan dalam al-Quran (QS 23: 8-11). Oleh karena itu cakupan kepemimpinan di dalam Islam yaitu kepemimpinan atas diri sendiri, kepemimpinan dalam sebuah komunitas dan kepemimpinan atas ide atau ideologis.

Secara istilah khalifah, Imam dan Amirul Mukminin adalah orang yang mewakili umat (rakyat) dalam menjalankan pemerintahan, kekuasaan dan penerapan huku-hukum syara'. Karena Islam telah menjadikan pemerintah dan kekuasaan tersebut menjadi milik umat. Dalam hal ini, umat mewakilkan kepada seseorang unutk melaksanakan urusan tersebut sebagai wakilnya. Bahkan, Allah SWT juga telah mewajibkan kepada umat untuk menerapkan hukum syara' secara keseluruhan (Zallum, 2002). Pengertian di atas diperkuat dengan mengemukakan pendapat Ath-Thabari dalam tafsirnya mengemukakan bahwa kata "imam" mempunyai makna yang sama dengan khalifah. Hanya saja kata imam digunakan untuk keteladanan. Karena ia diperoleh dari kata yang mengandung arti depan, berbeda dengan khalifah, yang terambil dari kata belakang. Beekun dan Badawi (dalam Fitrah, 2017).

\subsubsection{Unsur Kepemimpinan}

Setelah membahas pengertian kepemimpinan dan teori yang mendasarinya, secara umum terdapat empat unsur dalam kepemimpinan, yaitu: (adanya pemimpin), (2) adanya pengikut, (3) adanya sifat perilaku tertentu dan (4) adanya situasi dan kondisi tertentu. beberapa unsur tersebut tidak jauh berbeda dengan empat unsur kepemimpinan yang dirumuskan oleh Nawawi (1993). Yaitu:

a) Adanya seseorang yang berfungsi memimpin, yang disebut pemimpin

b) Adanya orang lain yang dipimpin 
c) Adanya kegiatan menggerakkan orang lain, yang dilakukan dengan mempengaruhi perasaan, pikiran dan tingkah lakunya

d) Adanya tujuan yang hendak dicapai, baik yang dirumuskan secara sistematis maupun bersifat sukarela

\subsubsection{Pengertian Kinerja}

Menurut (Bastian, 2006), kinerja adalah gambaran mengenai tingkat pencapaian pelaksanaan suatu kegiatan/program/kebijakan dalam mewujudkan sasaran, tujuan, visi, dan misi suatu organisasi yang tertuang dalam perumusan rencana strategis (strategic planning) suatu organisasi. Menurut (Mahsun 2014) kinerja bisa diketahui jika individu atau kelompok individu tersebut mempunyai kriteria keberhasilan yang telah ditetapkan. Kriteria keberhasilan ini berupa tujuan-tujuan atau target tertentu yang hendak dicapai. Tanpa ada tujuan atau target, kinerja seseorang atau individu tidak mungkin dapat dicapai karena tidak ada tolak ukurnya.

Hasibuan (2003) mengemukakan bahwa kinerja adalah suatu hasil kerja yang dicapai seorang dalam melaksanakan tugas-tugas yang dibebankan kepadanya yang didasarkan atas kecakapan, pengalaman dan kesungguhan serta waktu. Dengan kata lain bahwa kinerja adalah hasil kerja yang dicapai oleh seseorang dalam melaksanakan tugas yang diberikan kepadanya sesuai dengan kriteria yang ditetapkan. Selanjutnya As'ad mengemukakan bahwa kinerja seseorang merupakan ukuran sejauh mana keberhasilan seseorang dalam melakukan tugas pekerjaannya (Brahmasari \& Suprayetno, 2008).

\subsubsection{Teori-teori Kinerja}

a) Goal Theory

Teori ini dikemukakan oleh Georgopoulus (1975) yang disebut path goal theory. Menurutnya performance adalah fungsi dari facilitating process dan inhibiting process. Prinsip dasarnya adalah jika seseorang melihat bahwa performance yang tinggi itu merupakan jalur (path) untuk memuaskan need (goal) tertentu, maka ia akan berbuat mengikuti jalur tersebut sebagai fungsi dari level of needs yang bersangkutan.

Kesimpulan dari teori ini adalah bahwa performance atau kinerja yang tinggi apabila anggotanya merasa puas terhadap apa yang diberikan oleh organisasi, dalam hal proses menuju tujuan yang diharapkan dengan level tertentu.

b) Attribusi / Expectancy Theory

Pertama kali dikemukakan oleh Heider (1958), pendekatan teori atribusi ini mengenai kinerja yang dirumuskan sebagai berikut:

$\mathrm{P}=\mathrm{M} \times \mathrm{A}$

Keterangan:

$\mathrm{P}=$ Performance (kinerja)

$\mathrm{A}=$ Ability (kemampuan)

$\mathrm{M}=$ Motivation (motivasi)

Berdasarkan rumus diatas, teori kinerja (performance) adalah hasil interaksi antara motivasi (motivation) dan kemampuan (ability). 


\subsubsection{Kinerja Instansi Pemerintah}

Definisi kinerja instansi pemerintah sendiri menurut Keputusan Kepala Lembaga Administrasi Negara No:239/IX/6/8/2003 adalah gambaran mengenai tingkat pencapaian sasaran ataupun tujuan instansi pemerintah sebagai penjabaran dari visi, misi dan strategi instansi pemerintah yang mengindikasikan tingkat keberhasilan dan kegagalan pelaksanaan kegiatan-kegiatan sesuai dengan program dan kebijakan yang ditetapkan. Kinerja instansi pemerintah didasarkan pada masing-masing satuan kerja (Dinas) yang telah diberi wewenang mengelola sumber daya sebagaimana bidangnya.

Pemahaman mengenai konsep kinerja organisasi publik dapat dilakukan dengan 2 pendekatan. Pertama, melihat kinerja organisasi publik dari perspektif birokrasi itu sendiri. Kedua, melihat kinerja organisasi publik dari persepektif kelompok sasaran atau pengguna jasa organisasi publik. Kedua perspektif tersebut saling berinteraksi di antara keduanya, karena pemahaman mengenai konsep kinerja organisasi publik sangat terkait erat dengan lingkungan tempat organisasi publik hidup dan berkembang. Khusus mengenai organisasi publik berkaitan erat dengan produktivitas, kualitas layanan, responsivitas, responsibilitas, akuntabilitas, serta persamaan pelayanan. Konsep yang sering dipergunakan untuk melihat kinerja organisasi publik daerah sering dikaitkan dengan penggunaan anggaran. Konsep ini sering dikenal dengan istilah performance in term of themonetary calculus of efficiency (Mardiasmo, 2006).

\subsubsection{Akuntabilitas Kinerja Instansi Pemerintah Daerah}

Kata akuntabilitas berasal dari bahasa Inggris accountability yang berarti keadaan yang dapat dipertanggung jawabkan. Itulah sebabnya, akuntabilitas menggambarkan suatu keadaan atau kondisi yang dapat dipertanggung jawabkan. Akuntabilitas merupakan bentuk pertanggungjawaban pengelolaan sumber daya serta pelaksanaan kebijakan yang dipercayakan kepada entitas pelaporan dalam mencapai tujuan yang telah ditetapkan secara periodik (Mahsun dkk, 2007). Mardiasmo (2006) mengartikan akuntabilitas sebagai hubungan antara pihak yang memegang kendali dan mengatur entitas dengan pihak yang memiliki kekuatan formal atas pihak pengendali tersebut.

Sedangkan Akuntabilitas Kinerja Instansi Pemerintah (AKIP) adalah perwujudan kewajiban suatu instansi pemerintah untuk mempertanggungjawabkan keberhasilan dan kegagalan pelaksanaan misi organisasi dalam mencapai sasaran dan tujuan yang telah ditetapkan melalui sistem pertanggungjawaban secara periodik (LAN, 2003). Mardiasmo (2006) menyatakan bahwa akuntabilitas merupakan dasar pelaporan keuangan di pemerintah yang didasari oleh adanya hak masyarakat untuk mengetahui dan menerima penjelasan atas pengumpulan sumber daya dan penggunaannya. Pernyataan tersebut berarti memberikan ruang kepada masyarakat untuk menilai dan meminta pertanggung jawaban pemerintah atas semua aktivitas yang dilakukan pemerintah.

Akuntabilitas Kinerja Instansi Pemerintah dapat terwujud dengan baik apabila memenuhi persyaratan-persyaratan sebagai berikut LAN (2003): 
a. Beranjak dari sistem yang dapat menjamin penggunaan sumbersumber daya yang konsisten dengan asas-asas umum penyelenggaraan negara

b. Komitmen dari pimpinan dan seluruh staf instansi yang bersangkutan

c. Menunjukkan tingkat pencapaian sasaran dan tujuan yang telah ditetapkan

d. Berorientasi pada pencapaian visi dan misi, serta hasil dari manfaat yang diperoleh

e. Jujur, obyektif, transparan dan akurat

f. Menyajikan keberhasilan dan kegagalan dalam pencapaian sasaran yang telah ditetapkan.

\subsubsection{Konsep Pembangunan Ekonomi}

Pembangunan seringkali diartikan sebagai kemajuan yang dicapai oleh suatu masyarakat dibidang ekonomi (Rahmat, 2013). Pembangunan ekonomi adalah suatu rangkaian proses kegiatan yang dilakukan oleh suatu negara untuk mengembangkan kegiatan atau aktifitas ekonomi untuk meningkatkan taraf hidup atau kemakmuran (income per-kapita) dalam jangka panjang (Subandi, 2011). Pembangunan ekonomi juga merupakan suatu proses di mana pendapatan perkapita suatu negara meningkat selama kurun waktu yang panjang, dengan catatan bahwa jumlah penduduk yang hidup di bawah garis kemiskinan absolut tidak meningkat dan distribusi pendapatan tidak semakin timpang (Meier dalam Kuncoro, 2006). Dari pernyataan di atas dapat dipahami bahwa pembangunan ekonomi tidak hanya dilihat dari pendapatan perkapita suatu negara akan tetapi lebih luas dari itu yaitu melibatkan tingkat kesejahteraan atau kemakmuran masyarakat di suatu negara tersebut.

Fitrah (2017) juga mengemukakan pendapatnya mengenai pembangunan ekonomi, yaitu suatu proses yang bertujuan untuk menaikkan atau meningkatkan produk domestik bruto (PDB) suatu negara atau daerah melebihi tingkat pertumbuhan penduduk. Kenaikan pendapatan masyarakat diikuti pula oleh perubahan dalam struktur sosial dan sikap masyarakat. Dalam pembangunan ekonomi diperlukan faktor pendukung agar proses pembangunan dapat berjalan sesuai tujuan pembangunan. Menurut Jhingan (2012), salah satu faktor utama dalam pembangunan ekonomi ialah pembentukan atau pengumpulan modal. Pembentukan modal meliputi modal materil maupun modal manusia. Ada berbagai pendapat, bahwa dalam pembangunan ekonomi yang dibutuhkan hanya modal materil saja, tetapi ada juga yang berpendapat bahwa modal manusia juga dibutuhkan dalam pembangunan ekonomi. Dengan adanya pembentukan modal diharapkan tujuan pokok pembangunan akan tercipta.

\subsubsection{Konsep Pertumbuhan Ekonomi}

Pertumbuhan ekonomi adalah proses kenaikan kapasitas produksi suatu perekonomian yang diwujudkan dalam bentuk kenaikan pendapatan nasional. Sementara menurut Samuelson (2004) menjelaskan bahwa pertumbuhan ekonomi menunjukkan perkembangan GNP (gross national product) potensial di suatu negara.

Sementara menurut Ormedo (dalam Zulhelmy, 2013) ukuran pertumbuhan ekonomi melalui perhitungan pendapatan nasional atau national accounting yang 
dijadikan standar semua negara saat ini, baik maju maupun berkembang patut dipertanyakan. Karena pertumbuhan ekonomi dengan mengukur tingginya pendapatan nasional tidak menjamin terpenuhinya kebutuhan setiap individu secara keseluruhan. Menurutnya, bahwa kenyataan (terutama Indonesia) meskipun dengan tingginnya angka pertumbuhan ekonomi, yang bahkan berada pada tingkat fantastis, justru perekonomian negara mengalami kegoncangan, bahkan berada pada perekonomian yang ambruk, tingkat pengangguran semakin melabar, dan kemiskinan semakin tinggi.

Perbedaan signifikan terhadap tolak ukur pertumbuhan ekonomi (pembangunan ekonomi) dalam perspektif Islam dengan di luar Islam (kapitalisme), terletak pada pandangan tentang masalah utama dalam ekonomi. Menurut ari-Nabhani (dalam Fitrah, 2017), dalam ekonomi Kapitalis memandang bahwa masalah utama dalam ekonomi adalah masalah kelangkaan barang dan jasa (scarcity), banyaknya kebutuhan dan sedikitnya alat pemuas kebutuhan manusia. Artinya, jumlah barang dan jasa yang ada tidak akan bisa memenuhi seluruh kebutuhan manusia secara menyeluruh. Oleh karena itu, penyelesaian permasalahan tersebut yaitu dengan meningkatkan produksi barang dan jasa, tanpa memperhatikan apakah setiap individu sudah mendapati barang dan jasa yang telah diproduksi.

\subsubsection{Indeks Pembangunan Manusia}

IPM merupakan ukuran untuk melihat dampak kinerja pembangunan suatu negara yang mempunyai dimensi yang sangat luas, karena memperlihatkan kualitas penduduk suatu negara dalam hal harapan hidup, intelektualitas dan standar hidup layak. IPM menjelaskan bagaimana penduduk dapat mengakses hasil pembangunan, antara lain pendapatan, kesehatan, pendidikan, dan sebagainya.

IPM diperkenalkan oleh UNDP sejak tahun 1990, dengan definisi bahwa pembangunan manusia adalah suatu proses untuk memperbesar pilihan-pilihan bagi manusia (a process of enlarging peoples's choices) Dari definisi ini dapat ditarik kesimpulan bahwa fokus pembangunan suatu negara adalah manusia sebagai aset negara yang sangat berharga. Definisi pembangunan manusia tersebut pada dasarnya mencakup dimensi pembangunan yang sangat luas.

IPM sesungguhnya merupakan indikator pembangunan yang mempertimbangkan kebutuhan dasar manusia. Kebutuhan dasar adalah segala sesuatu yang jika tidak dipenuhi akan menghentikan kehidupan seseorang. Kebutuhan dasar ini meliputi makanan, pakaian, rumah, kesehatan dan keselamatan diri. Jika satu saja dari sekian banyak kebutuhan dasar ini tidak dipenuhi, maka muncullah keadaan yang disebut kemunduran absolut (Todaro, 2011).

Meningkatkan mutu sumber daya manusia dipandang sebagai kunci terhadap pembangunan yang dapat menjamin kemajuan ekonomi dan kestabilan sosial. Investasi harus diarahkan bukan saja untuk meningkatkan physical capital stock tetapi juga human capital stock dengan mengambil keutamaan pada usaha meningkatkan mutu pendidikan, kesehatan dan gizi (Tjokroamidjojo, 1995). 


\subsubsection{Filosofi Ekonomi Islam}

Latar belakang keilmuan Ekonomi Islam disebut sebagai Ontologi Ekonomi Islam yaitu berupa alasan mendasar adanya Ekonomi Islam. Sesuai dengan sistem kehidupan yang ada pada diri manusia, keluarga, lingkungan, dan alam semesta maka elemen dasar penciptaan terdiri dari 3 unsur yaitu manusia, Allah, dan ibadah. Kemudian perpaduan 3 hal ini membentuk alasan besar penciptaan yaitu Islam, sehingga ontology dari Ekonomi Islam adalah Islam. QS. Ali Imran [3]: 19, Artinya: "Sesunguhnya Din (sistem) di sisi Allah adalah Islam". Sesuai dengan firman Allah tersebut bahwa sistem atau Din yang diciptakan Allah itu hanya Islam. Sehingga sistem ekonomi yang ada seharusnya juga mengikuti aturan dalam sistem Islam (Aziz, 2009).

Islam dalam Ekonomi Islam merupakan konsep besar sebagai suatu sistem yang menyeluruh. Kemudian Islam yang menyeluruh inilah yang menjadi epistemology dari keilmuan Ekonomi Islam yang sedang berkembang yaitu kafah. Ekonomi Islam yang kafah muncul sebagai konsep dasar ekonomi dengan batasan Islam sebagai suatu sistem. QS. AlBaqarah [2]: 208, artinya: "Wahai orang-orang beriman masuklah kalian ke dalam Islam secara kafah".

\subsection{Penelitian Terdahulu}

Kajian pustaka tentang penelitian terdahulu bertujuan untuk mengetahui hubungan antara penelitian yang pernah dilakukan. Dibawah ini penulis akan memberikan kesimpulan hasil penelitian yang pernah dilakukan:

Tabel 1. Penelitian terdahulu

\section{No Nama peneliti, Tahun, Judul Penelitian $\quad \begin{aligned} & \text { Metode } \\ & \text { Analisis }\end{aligned} \quad$ Hasil Penelitian}

$1 \quad$ Mutiara Aliefty Octavina, Suryadi, Stefanus Pani Rengu (2014), Kepemimpinan Bupati Dalam Meningkatkan Pembangunan

(Studi tentang Kepemimpinan Bupati di Kabupaten Bangkalan 2003-2013)

2 Ahmad Zainuri (2011), Pengaruh Etika Kerja dan Kepemimpinan Islam Terhadap Kinerja Karyawan (Studi pada KJKS/UJKS Koperasi Kab. Pati)

3 Susilo Toto Raharjo, Durrotun Nafisah (2006), Analisis Pengaruh Gaya Kepemimpinan Terhadap Kepuasan Kerja, Komitmen Organisasi dan Kinerja Karyawan
Peningkatan pembangungan di $\begin{array}{ll}\text { interaktif } & \text { kabupaten tersebut dipengaruhi } \\ \text { dari Miles } & \text { oleh gaya kepemimpinan Bupati }\end{array}$ $\begin{array}{lll}\text { dari Miles } & \text { oleh gaya kepemimpinan Bupati } \\ \text { dan } & \text { dalam proses pengambilan }\end{array}$ huberman keputusan, penetapan kegiatan (1992) atau tugas, pemberian tugas atau penugasan, pemberian penghargaan dan kritik yang melibatkan masyarakat dan jajaran di bawahnya.

Regression Kepemimpinan Islam berpengaruh Models signifikan terhadap kinerja karyawan.

Regression Salah satu gaya kepemimpinan berpengaruh signifikan terhadap kepuasan kerja, komitmen organisasi dan kinerja karyawan. 
(Sudi empiris pada Departemen Agama kabupaten Kendal dan Departemen Agama kota Semarang)

Khairul Fitrah (2017), Pengaruh Kepemimpinan Islami Kepala Daerah dan Kinerja Pemerintah Daerah Terhadap Pembangunan Ekonomi Di Provinsi Riau

Siti Mustofiah (2015), Pengaruh Kepemimpinan Islami Terhadap Kinerja Karyawan Pada Rabbani Semarang
Structural Equation Modeling dengan sistem Lisrel

Analisis kuantitatif dan analisis regresi sederhana
Kepemimpinan Islami kepala daerah melalui kinerja pemerintah daerah berpengaruh terhadap pembangunan ekonomi di provinsi Riau. Namun secara simultan hubungan tersebut tidak signifikan.

Variabel kepemimpinan berpengaruh signifikan terhadap kinerja karyawan.

\subsection{Kerangka Pemikiran}

Kerangka pemikiran dalam penelitian ini dapat digambarkan sebagai berikut:

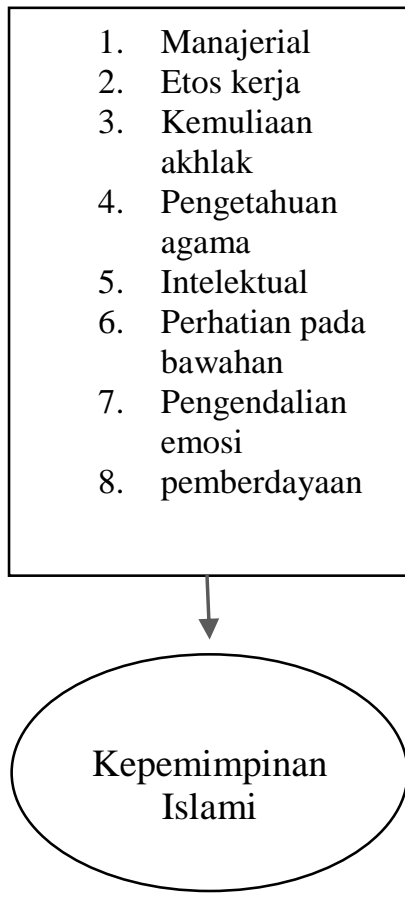

1. Sumber daya finansial

2. Kepatuhan terhadap hukum dan administrasi

3. Efisiensi dan ekonomis

4. Orientasi manfaat dan hasil

5. Intelektual

6. Perhatian pada bawahan

. Pengendalian

8. pemberdayaan 


\subsection{Hipotesis}

Hipotesis yang dikembangkan dalam peneitian ini adalah:

1. $\mathrm{H}_{0} \quad$ : Tidak ada pengaruh antara Kepemimpinan Islami Kepala

Daerah terhadap Pembangunan Ekonomi di KotaTangerang Selatan

$\mathrm{H}_{1} \quad$ : Ada pengaruh antara Kepemimpinan Islami Kepala Daerah terhadap Pembangunan Ekonomi di Kota Tangerang Selatan

2. $\mathrm{H}_{0} \quad$ : Tidak ada pengaruh antara Kepemimpinan Islami Kepala Daerah terhadap Akuntabilitas kinerja PemerintahanDaerah

$\mathrm{H}_{1} \quad$ : Ada pengaruh antara Kepemimpinan Islami Kepala Daerah terhadap Akuntabilitas kinerja Pemerintah Daerah

3. $\mathrm{H}_{0} \quad$ : Tidak ada pengaruh antara Akuntabilitas kinerja Pemerintahan Daerah terhadap Pembangunan Ekonomi di KotaTangerang Selatan

$\mathrm{H}_{1} \quad$ : Ada pengaruh antara Akuntabilitas kinerja Pemerintah Daerah terhadap Pembangunan Ekonomi di Kota TangerangSelatan

\section{METODOLOGI PENELITIAN}

\subsection{Ruang Lingkup Penelitian}

Penelitian ini akan mengukur dan menganalisis hubungan yang menjelaskan pengaruh dalam variabel independen, yaitu kepemimpinan Islami dan kinerja pemerintah terhadap variabel dependen, yaitu pembangunan ekonomi. Sehingga peneliti menetapkan jenis penelitian adalah penelitian kuantitatif dengan analisis kausal untuk mencari pengaruh antar variabel penelitian. Objek dalam penelitian ini adalah masyarakat yang tinggal di wilayah Kota Tangerang Selatan dan secara administratif merupakan penduduk Kota Tangerang Selatan (berada di bawah kepemimpinan dan pemerintahan Kota Tangerang Selatan). Penelitian ini menggunakan data primer melalui penyebaran kuesioner kepada 100 responden. Sehingga kuesioner merupakan sumber data utama penelitian ini.

\subsection{Metode Penelitian Sampel}

1. Populasi

Muis (2009) mendefiniskan populasi yaitu sekelompok orang, kejadian, atau gejala sesuatu yang mempunyai karakteristik tertentu. Anggota populasi disebut dengan elemen populasi. Masalah populasi timbul terutama pada penelitian opini yang menggunakan metode survei sebagai teknik pengumpulan data. Populasi bukan hanya terpaku pada manusia, tetapi juga bisa berupa obyek atau subyek yang dipelajari, tetapi meliputi seluruh karakteristik atau sifat yang dimiliki oleh obyek atau subyek itu (Mufraini 2013). Berdasarkan laporan tahunan Kota Tangerang Selatan (2016), jumlah populasi masyarakat di Kota Tangerang Selatan adalah sebesar 1.543.209 jiwa.

2. Sampel

Metode pengambilan sampel yang digunakan adalah non probability sampling yaitu teknik pengambilan sampel dimana setiap anggota populasi tidak memiliki kesempatan yang sama sebagai sampel. Teknik sampling yang digunakan adalah Purposive Sampling Menurut Muis (2009). Purposive Sampling yaitu merupakan teknik penarikan sampel 
yang dilakukan karena tujuan penelitian hanya dimaksudkan untuk mengungkap variabel sebatas dalam sampel itu saja. Sehingga berdasarkan pernyataan di atas, bahwa di dalam penelitian ini sampel yang digunakan adalah sebesar 100 responden masyarakat di Kota Tangerang Selatan. Selain itu untuk metode analisis PLS (Partial Least Square) yang didasari asumsi sampel tidak harus besar, yaitu jumlah sampel kurang dari 100 bisa dilakukan analisis (Ghozali, 2015).

\subsection{Metode Pengambilan Data}

1. Data Primer

Data primer adalah merupakan data yang bersumber dari responden secara langsung dan bukan dalam bentuk file-file (Sarwono, 2006). Dengan kata lain data primer merupakan data yang secara langsung berhubungan dengan responden.Tipe skala pengukuran yang digunakan adalah skala likert. Skala likert digunakan untuk mengukur sikap, persepsi, dan pendapat seseorang.

2. Data Sekunder

Data sekunder yang digunakan pada penelitian ini, yaitu dengan melakukan riset kepustakaan. Dimana peneliti melakukan studi kepustakaan, yang diperoleh dengan membaca buku-buku teori yang berhubungan dengan permasalahan penelitian yang diperoleh dari buku-buku referensi, artikel, jurnal dan data lain dari internet. Sementara data yang bersumber dari publikasi diperoleh dari Badan Pusat Statistik (BPS).

\subsection{Metode Analisis Data}

Metode analisis data dalam penelitian ini adalah dengan menggunakan Partial Least Square (PLS). Partial Least Square (PLS) merupakan metode analisis yang meniadakan asumsi-asumsi OLS (Ordinary Least Square) regresi, seperti data harus terdistribusi normal secara multivariate dan tidak adanya problem multikolonieritas antara variabel eksogen. Pada dasarnya,PLS dikembangkan untuk menguji teori yang lemah dan data yang lemah seperti jumah sampel yang kecil atau adanya masalah normalitas data (Wold 1982 pada Ghozali: 2015).

Analisis PLS-SEM biasanya terdiri dari dua sub model yaitu model pengukuran (measurement model) atau sering disebut outer model dan model structural (structural model) atau sering disebut inner model.

\section{Inner Model}

Inner model(inner relation, structural model dan substantive theory) menggambarkan hubungan atau kekuatan estimasi antar variabel laten atau konstruk berdasarkan pada substantive theory. Model persamaan inner model adalah sebagai berikut :

$$
\eta=\beta_{0}+\beta \eta+\Gamma \xi+\zeta
$$

Keterangan :

$\eta=$ Vektor variabel laten endogen (dependen)

$\xi=$ Vektor variabel laten eksogen (independen) 
$\zeta=$ Vektor residual (unexplained variance)

Dalam menilai model structural dengan PLS, kita mulai dengan melihat R-square untuk setiap variabel laten endogen sebagai kekuatan prediksi dari model structural. Interpretasinya sama dengan interpretasi pada OLS regresi. Perubahan nilai R-square dapat digunakan untuk menjelaskan pengaruh variabel laten eksogen tertentu terhadap variabel laten endogen apakan mempunyai pengaruh yang substantive. Nilai Rsquare $0.75,0.50$ dan 0.25 dapat disimpulkan bahwa model kuat, moderat dan lemah. Hasil dari PLS R-square merepresentasikan jumlah variance dari konstruk yang dijelaskan model. Disamping melihat besarnya Rsquare, evaluasi model PLS dapat juga dilakukan dengan $Q^{2}$ predictive relevance atau sering disebut predictive sample reuse yang dikembangkan oleh Stone (1974) dan eisser (1975). Teknik ini dapat mempresentasikan synthesis dari observed variabel dan estimasi dari parameter konstruk. (Ghozali; 2015)

\section{Outer Model}

Evaluasi pengukuran atau outer model dilakukan untuk menilai validitas dan reiabilitas model. Outer model dengan indicator refleksif dievaluasi melalui validitas convergent dan discriminant dari indicator pembentuk konstruk laten dan composite reliability serta conbrach's Alpha untuk blok indikatornya. Sedangkan Outer model dengan indokator formatif dievaluasi melalui substantive content-nya yaitu dengan membandingkan besarnya relative weight dan melihat signifikasi dari indicator konstruk tersebut (Chin 1998 dalam Ghozali; 2015).

Validitas convergent dari model pengukuran dengan model reflektif berhubungan dengan prinsip bahwa pengukur-pengukur (manifest variabel) dari suatu konstruk seharusnya berkorelasi tinggi. Uji validitas convergent indicator refleksif dengan program SmartPLS 3.0 dapat dilihat dari nilai loading factor untuk tiap indicator konstruk. Rule of thumb yang biasanya digunakan untuk menilain validitas convergent yaitu loading factor harus lebih dari 0.7 untuk penelitian yang bersifat confirmatory dan nilai loading faktor antara 0.6-0.7 untuk penelitian bersifat exploratory masih dapat diterima serta nilai average variance extracted (AVE) harus lebih besar dari 0.5. namun demikian untuk penelitian tahap awal dari pengembangan skala pengukuran nilai loading faktir 0.5-0.6 masih dianggap cukup (Chin, 1998 dakam Ghozali;2015).

Nilai average variance extracted (AVE) ini memiliki arti bahwa $50 \%$ atau lebih variance dari indicator dapat dijelaskan.

Selain uji validitas, pengukuran model juga dilakukan untuk menguji reliabilitas suatu konstrak. Uji reliabelitas digunakan untuk membuktikan akurasi, konsistensi dan ketepatan instrument dalam mengukur konstruk. Dalam PLS-SEM dengan mennggunakan SmartPLS 3.0, untuk mengukur reliabititas suatu konstruk dengan indicator refleksifdapat dilakukan dengan dua cara, yaitu dengan Conbach's Alpha dan Composite Reliability sering disebut Dillon-Goldstein's. Namun demikian penggunaan Conbach'sAlpha untuk menguji reliabilitas konstrk akan memberikan nilai yang lebih rendah (Under Estimate) sehingga lebih 
disarankan untuk menggunaka Composite Reliability dalam menguji reliabilitas suatu konstruk. Rule of Thumb yang biasanya digunakan untuk menilai reliabilitas konstruk yaitu nilai Composite Reliability harus lebih besar dari 0.7 untuk penelitian yang bersifat confirmatory dan nilai 0.6-0.7 masih dapat diterima untuk penelitian yang bersifat exploratory (Ghozali; 2015).

\subsection{Definisi Operasional}

Tabel 2. Definisi Operasional Variabel

\begin{tabular}{|c|c|c|c|}
\hline No & Variabel & Definisi Variabel & Indikator \\
\hline 1 & Kepemimpinan Islami & $\begin{array}{l}\text { Adalah proses atau upaya } \\
\text { menggerakkan, } \\
\text { membimbing dan } \\
\text { menunjukkan kepada orang } \\
\text { lain dalam rangka } \\
\text { melaksanakan syariat yang } \\
\text { diturunkan oleh Allah } \\
\text { SWT. }\end{array}$ & $\begin{array}{l}\text { a. Kemampuan manajerial } \\
\text { b. Etos kerja } \\
\text { c. Kemulyaan akhlak } \\
\text { d. Pengetahuan agama } \\
\text { e. Kemampuan intelektual } \\
\text { f. Perhatian pada bawahan } \\
\text { g. pemberdayaan } \\
\text { h. pengendalian emosi }\end{array}$ \\
\hline 2 & $\begin{array}{l}\text { Akuntabilitas Kinerja } \\
\text { Instansi Pemerintah }\end{array}$ & $\begin{array}{l}\text { Adalah perwujudan } \\
\text { kewajiban suatu instansi } \\
\text { pemerintah untuk } \\
\text { mempertanggung jawabkan }\end{array}$ & $\begin{array}{l}\text { a. Sumber daya finansial } \\
\text { b. Kepatuhan terhadap } \\
\text { hukum dan kebijaksanaan } \\
\text { administratif }\end{array}$ \\
\hline & & $\begin{array}{l}\text { keberhasilan/kegagalan } \\
\text { pelaksanaan organisasi } \\
\text { dalam mencapai tujuan dan } \\
\text { sasaran yang telah } \\
\text { ditentukan. }\end{array}$ & $\begin{array}{l}\text { c. Efisiensi dan } \\
\text { ekonomisnya suatu kegiatan } \\
\text { d. Hasil program yang } \\
\text { tercermin dari tujuan } \\
\text { manfaat dan efektivitas }\end{array}$ \\
\hline 3 & $\begin{array}{l}\text { Pembangunan } \\
\text { Ekonomi }\end{array}$ & $\begin{array}{l}\text { Adalah pembangunan } \\
\text { kemakmuran ekonomi } \\
\text { negara atau daerah guna } \\
\text { kesejahteraan } \\
\text { penduduknya. }\end{array}$ & $\begin{array}{l}\text { a. Pertumbuhan ekonomi } \\
\text { b. peningkatan lapangan } \\
\text { kerja } \\
\text { c. tingkat inflasi daerah } \\
\text { d. perkembangan ziswaf } \\
\text { e. investasi }\end{array}$ \\
\hline
\end{tabular}

\section{HASIL PPENELITIAN DAN PEMBAHASAN}

Penelitian ini menggunakan model Structural Equation Modelling (SEM) berbasis varian (Partial Least Square), dimana PLS-SEM ini bertujuan untuk menguji hubungan prediktif antar kinstruk dengan melihat apakah ada hubungan atau pengaruh antar konstruk terebut. Software yang digunakan dalam penelitian ini adalah SmartPLS 3.0 
Gambar 2. Output Calculate Alghoritm

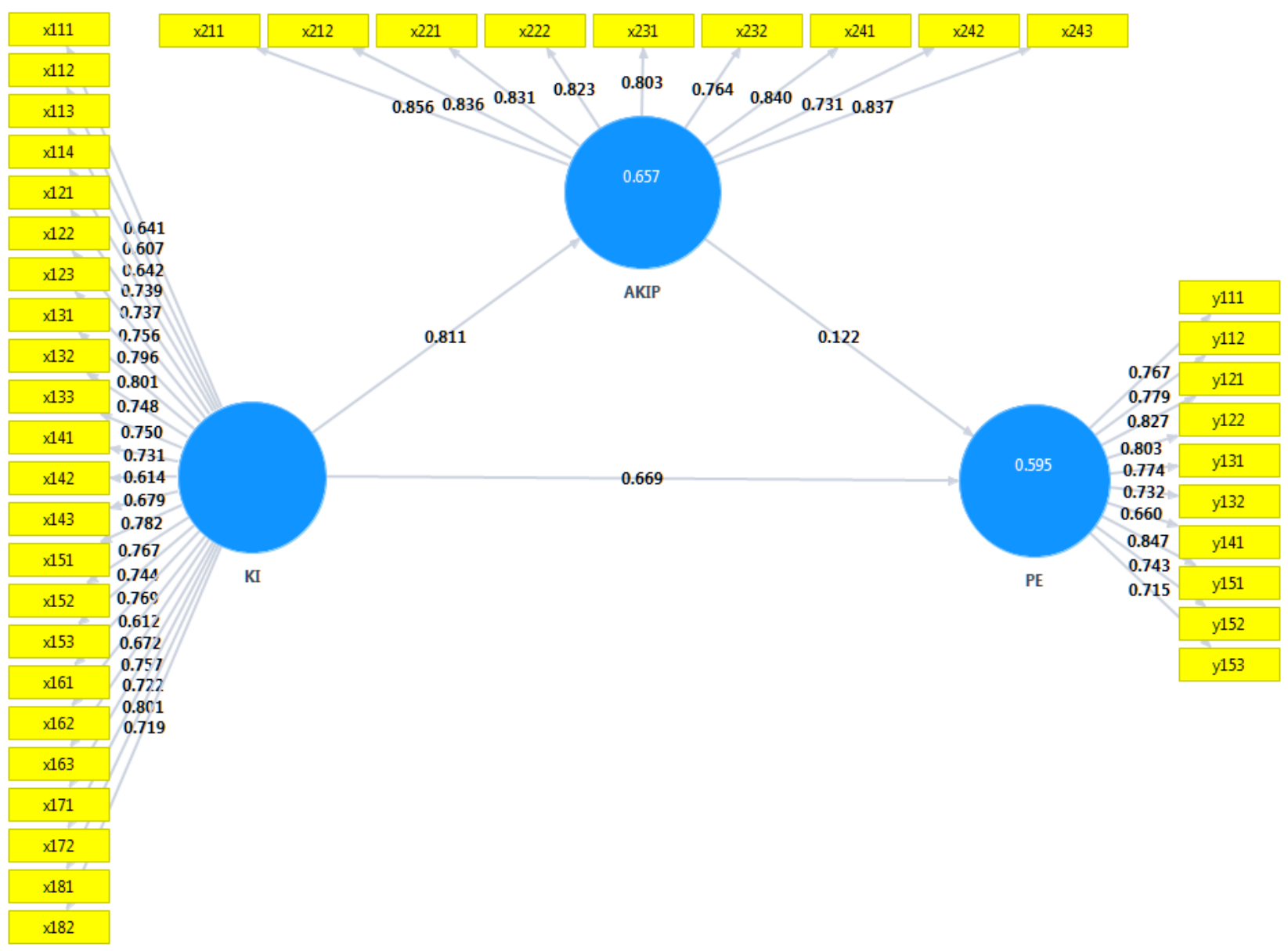

Sumber: data diolah dengan SmartPLS 
Pada Gambar Output Calculate Alghoritmmenunjukkan hasil penelitian dari masing-masing variabel yaitu, KI variabel kepemimpinan Islami yang memiliki 8 indikator (x111-x182), AKIP variabel akuntabilitas kinerja pemerintah daerah yang memiliki 4 indikator (x211-x243) dan PE variabel pembangunan ekonomi yang memilki 5 indikator (y111-y153). Indikator tersebut terdiri dari butir pertanyaan kuesioner. Arah panah antara indikator dengan konstruk laten adalah menuju konstruk yang menunjukan bahwa penelitian menggunakan indikator formatif yang bersifat mendefinisikan karakteristik atau menjelaskan konstruk.

\section{a. Uji Validitas}

Pengujian validitas untuk indikator formatif menunjukan adanya perubahan pada suatu indikator dalam konstruk jika indikator lain pada konstruk yang sama berubah atau dikeluarkan dari model.

Uji validitas dalam penelitian ini dapat dilihat dari uji convergen validity, dan dari nilai AVE. hasil output dari uji validitas dapat dilihat di bawah ini.

Tabel 3. Hasil Outer Loading

\begin{tabular}{|c|c|c|c|}
\hline & $\mathrm{KI}$ & AKIP & $\mathrm{PE}$ \\
\hline X111 & 0.641 & & \\
\hline $\mathrm{X} 112$ & 0.607 & & \\
\hline $\mathrm{X} 113$ & 0.642 & & \\
\hline X114 & 0.739 & & \\
\hline X121 & 0.737 & & \\
\hline $\mathrm{X} 122$ & 0.756 & & \\
\hline $\mathrm{X} 123$ & 0.796 & & \\
\hline X131 & 0.801 & & \\
\hline $\mathrm{X} 132$ & 0.748 & & \\
\hline X133 & 0.750 & & \\
\hline X141 & 0.731 & & \\
\hline X142 & 0.614 & & \\
\hline X143 & 0.679 & & \\
\hline X151 & 0.782 & & \\
\hline X152 & 0.767 & & \\
\hline X153 & 0.744 & & \\
\hline X161 & 0.769 & & \\
\hline X162 & 0.612 & & \\
\hline X163 & 0.672 & & \\
\hline $\mathrm{X} 171$ & 0.757 & & \\
\hline X172 & 0.722 & & \\
\hline X181 & 0.801 & & \\
\hline X182 & 0.719 & & \\
\hline X211 & & 0.856 & \\
\hline $\mathrm{X} 212$ & & 0.835 & \\
\hline X221 & & 0.831 & \\
\hline X222 & & 0.823 & \\
\hline X231 & & 0.803 & \\
\hline $\mathrm{X} 232$ & & 0.764 & \\
\hline $\mathrm{X} 241$ & & 0.840 & \\
\hline X242 & & 0.731 & \\
\hline X243 & & 0.837 & \\
\hline Y111 & & & 0.767 \\
\hline
\end{tabular}


$\begin{array}{ll}\text { Y112 } & 0.779 \\ \text { Y121 } & 0.827 \\ \text { Y122 } & 0.803 \\ \text { Y131 } & 0.774 \\ \text { Y132 } & 0.732 \\ \text { Y141 } & 0.660 \\ \text { Y151 } & 0.847 \\ \text { Y153 } & 0.743 \\ & 0.715\end{array}$

Sumber: data diolah dengan SmartPLS

Tabel di atas menunjukan bahwa nilai loading faktor dalam setiap konstruk lebih dari nilai loading faktor yang disarankan, yakni $>0.5$. Indikator dianggap valid jika memperlihatkan seluruh outer loading dimensi variabel memiliki nilai loading > 0.5 (Chin dalam Gozali, 2015). Nilai indikator yang paling rendah ada pada indikator X112 dengan nilai sebesar 0.607 dan indikator yang memiliki nilai tertinggi X211 sebesar 0.856, maka indikator dalam penelitian ini dinyatakan valid atau memenuhi uji convergent validity. Kemudian akan dilakukan metode lain dalam melihat discriminant validity adalah dengan melihat nilai square root of average extracted (AVE). Nilai AVE yang disarankan agar dapat dikatakan memenuhi syarat uji discriminant validity adalah lebih dari 0.5. Dengan output sebagai berikut:

Tabel 4. Average Variance Extracted (AVE)

\begin{tabular}{cc} 
& AVE \\
\hline KI & 0.524 \\
AKIP & 0.663 \\
PE & 0.588
\end{tabular}

Sumber: data diolah dengan SmartPLS

Dari Tabel di atas dapat diketahui bahwa nilai AVE dari setiap konstruk lebih dari 0.5 yakni KI (Kepemimpinan Islami) memiliki nilai 0.524, AKIP (Akuntabilitas Kinerja Pemerintah daerah) memiliki nilai 0.663, serta PE (Pembangunan Ekonomi) memiliki nilai 0.588. Dengan demikian dapat dinyatakan bahwa konstruk ini memenuhi uji discriminant validity.

\section{b. Uji Reliabilitas}

Uji reliabilitas pada penelitian ini dilihat dari nilai cronbachs Alpha yang dihasilkan dari setiap konstruk. Hasil cronbachs Alpha yang dapat dikatakan memenuhi uji reliabilitas apabila lebih dari 0.70 . Berikut adalah output dari uji Cronbachs Alpha.

Tabel 5. Hasil Cronbachs Alpha

Cronbachs Alpha.

\begin{tabular}{cc}
\hline KI & 0.958 \\
AKIP & 0.937 \\
PE & 0.921
\end{tabular}

Dari di atas dapat dilihat bahwa nilai cronbachs Alpha dari setiap konstruk sangat baik yakni diatas 0.70 dengan kepemimpinan Islami (KI) 
sebesar 0.958, akuntabilitas kinerja pemerintah daerah (AKIP) sebesar 0.937, dan pembangunan ekonomi (PE) sebesar 0.921. Dengan demikian dapat disimpulkan bahwa semua indikator konstruk adalah reliabel atau memenuhi uji reliabilitas.

Kemudian uji reliabilitas dalam penelitian ini juga dapat diperkuat dengan uji composite reliability. Agar dapat dinyatakan memenuhi uji reliabilitas nilai composite reliability yang disarankan harus lebih dari 0.70 . Berikut hasil output composite reliability.

Tabel 6. Hasil Composite Reliability

\begin{tabular}{cc} 
& Composite Reliability \\
\hline KI & 0.962 \\
AKIP & 0.946 \\
PE & 0.934 \\
Sumber: data diolah dengan SmartPLS
\end{tabular}

Dari Tabel di atas dapat dilihati bahwa nilai composite reliability dari setiap konstruk sangat baik yakni diatas 0.70 dengan KI sebesar 0.962, AKIP sebesar 0.946, dan PE 0.934. Dengan demikian dapat disimpulkan bahwa semua indikator konstruk adalah reliabel atau memenuhi uji reliabilitas.

Dapat dilihat juga bahwa nilai composite reliability lebih tinggi untuk semua konstruk dibandingkan dengan nilai cronbachs alpha. Hal ini juga memperkuat penelitian bahwa konstruk dalam penelitian ini memenuhi uji reliabilitas.

\section{c. Uji Hipotesis}

Dalam Dalam melakukan pengujian hipotesis, dalam penelitian ini dilakukan uji $\mathrm{T}$ dan nilai R-Square Adjusted $\left(\mathrm{R}^{2}\right)$. Kriteria penerimaan dan penolakan hipotesis yang digunakan dalam penelitian menggunakan uji $\mathrm{T}$ dan melihat besaran nilai R-Square Adjusted $\left(\mathrm{R}^{2}\right)$.

1. Uji T

Hipotesis penelitian dapat diterima jika nilai t hitung (t-statistik) lebih dari t tabel pada tingkat kesalahan 1.96. berikut ini merupakan nilai dari $\mathrm{t}$ hitung ( $\mathrm{t}$-statistik) berdasarkan path coefficient yang dihasilkan dari analisis.

Tabel 7. Hasil Uji T

\begin{tabular}{|c|c|c|c|}
\hline & Original Sampel & T-Statistik & P Values \\
\hline $\mathrm{KI} \longrightarrow \mathrm{PE}$ & 0.669 & 6.817 & 0.000 \\
\hline $\mathrm{KI} \longrightarrow \mathrm{AKIP}$ & 0.811 & 16.007 & 0.000 \\
\hline $\mathrm{AKIP} \rightarrow \mathrm{PE}$ & 0.122 & 1.063 & 0.288 \\
\hline
\end{tabular}

Pengujian hipotesis pertama $\mathrm{H}_{0}$ ditolak dan $\mathrm{H}_{1}$ diterima, dari nilai koefisien path dari Tabel di atas dapat dilihat ada pengaruh positif signifikan antara kepemimpinan Islami (KI) terhadap pembangunan ekonomi (PE). Dengan nilai t-statistik KI sebesar 6.817 dan nilai p value sebesar 0.000 . Keduanya telah lebih besar dari pada tingkat ttabelnya yaitu 1.96 dan telah memenuhi signifikan di bawah 0.05 . 
Dari nilai koefisien path dapat dilihat bahwa kepemimpinan Islami (KI) memiliki pengaruh positif terhadap akuntabilitas kinerja pemerintah daerah (AKIP), hal ini dikarenakan t-statistik yang dimiliki KI lebih dari t tabel 1.96 yakni sebesar 16.007, dan telah memenuhi nilai signifikan di bawah 0.05 yaitu dengan nilai $\mathrm{p}$ values 0.000 . Dengan hasil tersebut, maka hipotesis pertama pada penelitian ini H0 ditolak dan H1 diterima. Sehingga dapat disimpulkan bahwa kepemimpinan Islami memiliki pengaruh positif signifikan terhadap akuntabilitas kinerja pemerintah daerah.

Selanjutnya pengujian hipotesis ke tiga adalah $\mathrm{HO}$ diterima dan H1 ditolak. Dilihat dari nilai koefisien path pada Tabel di atas bahwa akuntabilitas kinerja pemerintah daerah (AKIP) tidak berpengaruh terhadap pembangunan ekonomi (PE). Karena nilai t-statistik yang didapatkan sebesar 1.063 lebih kecil dari t-tabel yaitu sebesar 1.96, dan nilai $\mathrm{p}$ value juga lebih besar dari nilai signifikansi yaitu sebesar 0.288 dari 0.05 .

2. Uji R-Square Adjusted $\left(R^{2}\right)$

Tabel 8. Hasil $R$-Square Adjusted $\left(\mathrm{R}^{2}\right)$

\begin{tabular}{cc} 
& R-Square Adjusted $\left(\mathrm{R}^{2}\right)$ \\
\hline AKIP & 0.654 \\
PE & 0.586 \\
& Sumber: data diolah dengan SmartPLS
\end{tabular}

Dari Tabel 8 di atas dapat diihat bahwa, nilai R-square variabel kinerja pemerintah daerah (AKIP) sebesar 0.654 yang artinya variabel kepemimpinan Islami (KI) mampu menjelaskan pengaruhnya terhadap variabel AKIP sebesar 65,4\% sedangkan 34,6\% dipengaruhi oleh varibel lain di luar model yang diteliti. Sedangkan nilai R-Square variabel pembangunan ekonomi (PE). Selatan sebesar 0.586 yang artinya variabel kepemimpinan Islami (KI) dan variabel akuntabilitas kinerja pemerintah daerah (AKIP) mampu mempengaruhi variabel PE sebesar 58,6\% sedangkan 41,4\% dipengaruhi oleh variabel lain di luar model yang diteliti.

\section{SIMPULAN DAN SARAN}

\subsection{Simpulan}

Berdasarkan analisis dan pembahan yang telah dilakukan pada bab sebelumnya, maka dapat diambil kesimpulan:

1. Hasil penelitian menunjukkan bahwa Kepemimpinan Islami kepala daerah berpengaruh signifikan terhadap pembangunan ekonomi di Kota Tangerang Selatan. Artinya kepemimpinan mempunyai pengaruh yang besar terhadap keberhasilan organisasi, dalam penelitian ini keberhasilan organisasi adalah terjadinya pembangunan ekonomi masyarakat. Faktor Islam yang tertanam pada kepemimpinan kepala daerah meningkatkan kemaslahatan dalam bidang spiritual (keagamaan) maupun dalam bidang sosial ekonomi masyarakat. Sebagai pemimpin duniawi, pemimpin wajib mengurusi kepentingan umum umat manusia dengan segala kemampuannya (ibn Khaldun dalam Al Mawardi, 2006) 
2. Hasil penelitian ini menunjukkan bahwa Kepemimpinan Islami kepala daerah berpengaruh signifikan terhadap akuntabilitas kinerja pemerintahan daerah di kota Tangerang Selatan. Artinya kepemimpinan memeberikan porsi yang besar untuk mendorong kinerja bawahannya/karyawannya yang lebih tinggi, sebagaimana yang dinyatakan dalam teori path goal. Kepemimpinan Islami yang mengacu pada prilaku Rasulullah SAW adalah amanah, dengan kata lain bertanggung jawab atau akuntabel.

3. Hasil penelitian ini menunjukkan bahwa akuntabilitas kinerja pemerintahan daerah tidak berpengaruh terhadap pembangunan ekonomi di Kota Tangerang Selatan. Artinya untuk mewujudkan pembangunan ekonomi tidak hanya akuntabilitas pemerintahan saja yang dilakukan, akan tetapi lebih kepada pemerintah daerah harus meningkatkan pelayanan publik, tersedianya lapangan pekerjaan, dan kebutuhan dasar masyarakat terpenuhi.

\subsection{Saran}

Berdasarkan kesimpulan yang telah diuraikan di atas, maka penulis mencoba menyampaikan saran yang diharapkan dapat membantu dan bermanfaat, diantaranya:

1. Penelitian selanjutnya diharapkan dapat meneliti dengan variabel yang berbeda karena dari hasil yang didapat masih ada variabel yang dapat mempengaruhi pembangunan ekonomi. Serta, diharapkan dapat meneliti dengan sampel yang lebih besar lagi untuk dapat lebih mewakili populasi tersebut.

2. Bagi pemerintah daerah Kota Tangerang Selatan penelitian ini dapat membantu, bahwa kepemimpinan yang berlandaskan Islam dalam menjalankan pemerintahan dapat meningkatkan kinerja bawahan/aparatur daerah dan mewujudkan pembangunan ekonomi.

\section{DAFTAR PUSTAKA}

Aminah, Siti Chaniago. 2010. "Kepemimpinan Islam dan Konvensional (Studi perbandingan)". RELIGIA Vol. 13, No. 2, Pp 239-254

Aziz, Roikhan Mochamad. 2009. New Paradigm on Sinlammim Kaffah In Islamic Economics. Jurnal Ilmu Ekonomi, Fakultas Ekonomi Bisnis, Universitas Islam Negeri Syarif Hidayatullah, Jakarta.

Aziz, Roikhan Mochamad. 2010. Ekonomi Moneter Tiga Dimensi. Modul Kuliah, Fakultas Ekonomi Bisnis, Universitas Islam Negeri Syarif Hidayatullah, Jakarta.

Bappeda Tangerang Selatan. 2016

BPS. 2017. Perkembangan Ekonomi Tangerang Selatan, Badan Pusat Statistik.

Brahmasari dan Suprayetno. 2008. "Pengaruh Motivasi Kerja, Kepemimpinan dan Budaya Organisasi Terhadap Kepuasan Kerja Karyawan serta Dampaknya pada Kinerja Perusahaan (Studi Kasus pada PT. Pei Hai International Wiratama Indonesia)., Universitas 17 Agustus Surabaya

Deliarnov. 2006. "Ekonomi Politik". Jakarta: Erlangga

Dessler, Gary. 2009. "Manajemen Sumber Daya Manusia”. Jakarta: Indeks 
Djunaedi, Zulkifli. 2005. "Prinsip Dasar Manajemen Risiko (Risk Management). FKM UI, Depok.

Fithrah, Khairul. 2017. "Pengaruh Kepemimpinan Islami Kepala Daerah dan Kinerja Pemerintah Daerah Terhadap Pertumbuhan Ekonomi Di Provinsi Riau”. Universitas Trisakti, Jakarta.

Ghozali, Imam dan Hengky Latan. 2015."Partial Least Square Konsep Teknik dan Apliksai menggunakan program SmartPLS 3.0 untuk Penelitian Empiris". Badan Penerbit Universitar Diponegoro.

Griffin, Ricky. 2000. “Management”. Edisi kedua. Jakarta: Erlangga

Hakim, Lukman. 2011. "Analisis Pengaruh Budaya Organisasi Terhadap Kinerja Karyawan”, Studi kasus PDAM Kota Surakarta, LPPM Universitas Muhammadiyah Surakarta

Ilfi, Nur diana. 2011. "Konsep dan Implementasi Kepemimpinan Islami di UIN Maliki Malang”. UIN Maliki Malang

Jhingan M.L. 2012. “Ekonomi Pembangunan dan Perencanaan". Jakarta: PT.Raja Grafindo Persada

Lembaga Administrasi Negara (LAN). 2003. "Penyusunan Standar Pelayanan Publik". LAN. Jakarta

Muis, Moh. Sidiq Priadana Saludin. 2009. "Metodologi Penelitian Ekonomi dan Bisnis”, Graha Ilmu, Yogyakarta

Rahmat. 2013. “Dimensi Strategis Manajemen Pembangunan”. Yogyakarta: Graha Ilmu

Rahmawaty, Anita. 2013. "Distribusi Dalam Ekonomi Islam”. STAIN Kudus Vol.1, No.1

Rivai, Veithzal dan Arviyan Arifin. 2009. "Islamic Leadership: Membangun Super Leadership Melalui Kecerdasan Spiritual”. Jakarta: PT. Bumi Aksara

Samuelson, Paul A. Dan Nordhaus, William. 2004. "Ilmu Makro Ekonomi". Jakarta: Media Global Edukasi

Sarwono, Jonathan. 2006. "Metode Penelitian Kuantitatif dan Kualitatif", Yogyakarta: Graha Ilmu

Subandi. 2011. "Ekonomi Pembangunan”. Bandung: Alfabeta

Sudarmanto. 2009. "Kinerja dan Pengembangan Kompetensi SDM”. Yogyakarta:

Pustaka

Pelajar

Todaro, Michael P. 2011. "Pembangunan Ekonomi di Dunia Ketiga". Jakarta: Erlangga

Vidayani, Fitria Ayu. 2012. "Dampak Pemekaran terhadap Perkembangan Kota Tangerang Selatan”. jurnal Perencanaan Wilayah dan Kota A SAPPK Vol.1, No.1

Zallum, Abdul Qadim, 2004. "Al-Amwal fi Daulah Al-Khilafah"

Zulhelmy. 2013. "Isu-isu Kontemporer Ekonomi dan Keuangan Islam”. Al Azhar Press 